Article

\title{
No (Wo) Man is an Island: Sexual Difference in Derrida and Beyond
}

Ashley J. Bohrer

\begin{abstract}
In reading together Robinson Crusoe and both volumes of The Beast and The Sovereign, I hope to replace the absence of women on Robinson Crusoe's island with a presence in Derrida's world of only islands. Doing so will perhaps open onto a productive dimension to the ever-present question of sovereignty. For indeed, Derrida writes, "A little as though there were some secret contract between sovereign euphoria, paradisaical euphoria, and the absence of women. Desire and the spectre of the female, sexuality and sexual difference are always conceived as limitations to the rational sovereignty of man over world, over his little island he calls 'world.' This reading, however, will not be easy. Though the question of sexual difference emerges throughout both volumes, Derrida does not treat the problem systematically in these texts. Before embarking on a reading of sexual difference in The Beast and The Sovereign, it will thus be necessary to take a detour through his text which does so: Geschlecht II. His remarks in this volume clearly underlie all of the references, questions, allusions, and problems of sexual difference posed.
\end{abstract}

Keywords: Derrida, sexual difference, woman, gender

$\mathrm{I}$ $\mathrm{n}$ the Second Session of The Beast and the Sovereign, Volume II, Derrida makes an almost unbelievable observation about Daniel Defoe's Robinson Crusoe: it contains pas de trace de pas de femme. There are no women on Robinson's island, nor even a trace of a woman long since departed. Derrida writes, "there are on this island only men and beasts... And when I say men, I mean men, not only humans but men without women and without sex."1 In a certain sense, this makes Robinson Crusoe the perfect text to read in the context of this seminar called The Beast and the Sovereign; after all, there are only (sovereign) men and beasts. But this also makes Robinson Crusoe a thoroughly strange choice to read in a seminar which opens with the question of sexual difference: "la... le," three times over the opening

${ }^{1}$ Jacques Derrida, The Beast and the Sovereign, Volume II (Chicago: University of Chicago Press, 2011), 91.

(c) 2013 Ashley J. Bohrer

http://www.kritike.org/journal/issue_12/bohrer june2013.pdf

ISSN 1908-7330

(cc)) BY-NC 
call of the first session, the call to consider the femininity of the beast [la bête] and the maleness of the sovereign [le souverain] and the erotic relation in which they become articulated. The first words of the first volume of this course entreat us to take seriously the question of sexual difference (if, in fact, one can still speak of such a thing) and the gendered, eroticized overtones of the question of man itself. It may be precisely for this reason, for the systematic 'forgetting' of women, for the ability to highlight the question of sex by its absence that Derrida chooses Defoe's Robinson as the subject of the second year of the course.

In fact, Derrida in a certain sense posits the compelling nature of the discourse of the island in the Western cultural context precisely as a space which offers the absence of sexual difference. He writes, "This is no doubt what explains in part the profound affect that attracts and attaches readers the world over [to Robinson's island], readers become children again, dreaming of such a paradisiacal place in spite of all the dangers that Robinson Crusoe seems to confront and fear. As if, like in Paradise, sexual difference has not yet taken place or no longer had any reason for being." ${ }^{\prime 2}$ The myriad texts and narratives of island shipwrecks of which Robinson Crusoe is paradigmatic, compel and grip us precisely insofar as they cover over sexual difference. In this way, Derrida himself conceives of the island as the constitutive absence of women, femininity, desire, and sexuality.

Surprising and compelling as Derrida's observation of the pas de trace de pas de femme remains, the remark seems fleeting, an island itself in the larger text of the second year. While the first year of the course constantly makes reference to the problem of sexual difference, in the second year, islands form the constitutive thematic. The question of sex surfaces only in the span of a few pages in the second session. It seems as though in the consideration of the rich, multiplicitous, polysemous figure of the island, the pas de trace is the only trace of the question of sexual difference.

But I propose to reread carefully and meticulously this moment of intersection, the few lines in which the problem of sexual difference meets the discourse of the island. In reading together Robinson Crusoe and both volumes of The Beast and the Sovereign, I hope to replace the absence of women on Robinson Crusoe's island with a presence in Derrida's world of only islands. Doing so will perhaps open onto a productive dimension to the ever-present question of sovereignty which frames the entire seminar. For indeed, Derrida writes, "A little as though there were some secret contract between sovereign euphoria, paradisaical euphoria, and the absence of women, of the other as woman, even the desire of or for the other as woman... that's sovereignty, that's solitary and exceptional sovereignty: slave, animal, and no woman. No desire to come along and limit sovereignty. In any case, no heterosexual desire." ${ }^{\text {3 }}$ Derrida here clearly recognizes

$$
\begin{aligned}
& { }^{2} \text { Ibid. } \\
& { }_{3}^{3} \text { Ibid., } 92 .
\end{aligned}
$$


that there is something in the thinking of the subject as non-sexual which is constitutive of sovereignty as that myth is perpetuated through the Western cannon. Desire and the spectre of the female, sexuality and sexual difference are always conceived as limitations to the rational sovereignty of man over world, over his little island he calls 'world.' This reading, however, will not be easy. Though the question of sexual difference emerges throughout both volumes, Derrida does not treat the problem systematically in these texts. Before embarking on a reading of sexual difference in the Beast and the Sovereign, it will thus be necessary to take a detour through his text which does so: Geschlecht II. His remarks in this volume clearly underlie all of the references, questions, allusions, and problems of sexual difference posed in the lecture course.

\section{Geschlecht II and Sexual Difference as Problem}

In Geschlecht II, Derrida takes up the question of the relationship between sexual difference and the ontological difference found in Heidegger's texts. The subject of Dasein seems always posed as the subject without sex, the subject prior to all sexual determination. And while in this essay, Derrida poses the question of the neutered subject specifically in relation to Heidegger's Dasein, it is clear that he also poses the question more generally to the history of the discourse of subjectivity in the West which poses a non-sexual, rational person as the universal structure of subjectivity which underlies all humans, be they male or female. When philosophy posits a subject of analysis, when it claims that this subject is not a sexed subject, when it claims that sexual difference is an external, accidental, or incidental characteristic of human beings, how seriously can we take this claim? Especially when, more often than not, this claim is merely asserted or forms a basic, uncritical presupposition? As many scholars have noted, the discourse of the subject-asneuter serves in many places to cover over the fact that the subject posed is always a white bourgeois male, even when the subject is supposedly stripped of these concrete determinations. Faced with similar criticisms, Heidegger is forced to take into account the question of sexual difference and Derrida re-presents Heidegger's answer thus: "Every body is sexed and Dasein is nothing without its body, but the dispersive multiplicity [which Dasein is] is not due to sex, but is drawn into sexual difference split from sexuality and toward a 'determinate sex."'4 Here Derrida's Heidegger splits the concept of sexuality from the determinations of binary sexuality. Derrida finds in this answer something redeemable about Heidegger's Dasein: that sexuality, even as an indeterminate primordial sexuality, must be ontologically relevant to its constitution. Heidegger thus comes a long way in thinking the relationship of subject and body in the realm of ontology. But, as

\footnotetext{
" Jacques Derrida, "Heidegger's Hand: Geschlecht II,” in Psyche: Inventions of the Other, trans. Peggy Kamuf and Elizabeth Rottenberg (Stanford: Stanford University Press, 2008), 75.
} 
Derrida notes, Heidegger's formulation still rests on the logic of binary sexuality, which splits humans definitively into male and female categories. The 'determinate sex' into which Dasein is drawn is always for Heidegger specific, rigid, uncritical determinations which generalize the destructive logic of the binary onto the composition of bodies themselves. Derrida thus poses the following question: "May one not begin to think of sexual difference without negativity, not sealed by a two? Not two yet or no longer?"5

Derrida leaves his analysis at the level of the question in Geschlecht II. The invocation of a non- binary sexuality which touches the realm of the ontological is left as provocation, question, open inquiry. But I want to argue that Derrida returns precisely to this question of sexual difference as binary in The Beast and the Sovereign in the polemical proposition that "there is no world, there are only islands." To explain this connection, I would like now to reconstruct the discourse of the island in this volume.

\section{Islands and the Topology of Sexual Difference}

In order to understand the status of the island in Derrida, it is necessary to reconstruct the structural role that the concept plays in various philosophical registers, ones that might provisionally be called ontological, theological, political, and aesthetic. In The Beast and the Sovereign, the concept of the island is first articulated between the two poles of man and animal. In the first session of Volume II, the island emerges as an ontological concept by way of three theses that Derrida poses about the status of world. He writes:

1. Incontestably, animals and humans inhabit the same world, the same objective world... 2. Incontestably, animals and humans do not inhabit the same world, for the human world will never be purely and simply identical to the world of animals. 3. In spite of this identity and this difference... [no] animal or human individual inhabit [s] the same world as another, however close and similar these living individuals may be.... between my world and any other world, there is first the time and space of an infinite difference, an interruption that is incommensurable with all attempts to make a passage, a bridge, and isthmus, all attempts at communication, translation, trope, and transfer that the desire for a world or the want of a world, the being wanting a

${ }^{5}$ Ibid., 83.

(C) 2013 Ashley J. Bohrer http://www.kritike.org/journal/issue 12/bohrer june2013.pdf ISSN 1908-7330 
world will try to pose, impose, propose, stabilize. There is no world there are only islands. ${ }^{6}$

There can be no mistake that Derrida's conclusion here stakes the world itself as lost concept, unable to articulate the state of affairs in which we find ourselves. Where once the world formed the basis of the possibility of interaction between individuals, this world is irrecoverably lost and perhaps never existed at all. The loss of the world is grounded in a deep thinking of experience. Every individual (human or animal), community, species, etc., has a unique experience and the long history of those interactions, determination, subjections, conditions can never be the same across those differences. For Derrida, this forms a completely constitutive yet inarticulable difference between any two beings such that this gap can never be bridged, overcome, or sutured together.

But the analysis becomes even more intriguing when we replace the relation between man and animal in these theses with the relationship between men and women, the relationship between the binary poles of sexual difference. To do so yields the following results:

1) Incontestably, men and women share the same objective world. 2) Incontestably, men share a world and women share a different world, separated by a variety of historical, economic, cultural, political and social conditions which treat men and women differently, which structure them as subjects in a differential relation, a differential which is always binary. 3) Incontestably, each person's sexuality is irreducibly singular, separated by the space and time of an infinite difference, such that no person's sexuality may be fully transmitted, translated, or categorized. Every sexuality is a unique sexuality. There is no sexual world to be had, there are only islands of sexual emergence.

Just as the three theses about man and animal implode the categories themselves, the logic of the island here serves to break down the poles of the sexual binary. Insofar as each individual's sexuality emerges as irreducibly singular, constituted by a whole host of differing personal and sexual experiences, conditions and injunctions, the imposed categories of male and female, whether referring to sex or to gender, serve only to cover over the real constitution of desire. We could take the analysis of sex even further. Insofar as the curves, outlines, size, sensations, folds, colors, responses, movements of each body are irreducibly singular, there can be no 'true sex', no biological referent for a binary conception of sex.

One can very easily see here Derrida fulfilling the promise and provocation which comes at the end of Geschlecht II. In staking out the island as the new topos of ontology, as the structure of the plane not only of experience, but also of existence, we see in a concrete way how, for Derrida, the ontological difference between me and another, between me and my other, must always be, at least in part, a sexual

${ }^{6}$ Derrida, The Beast and the Sovereign (Volume II), 31. 
difference. In so far as there is pas de trace de pas de femme on Robinson Crusoe's island, that is because the entire structure of la femme as such is a phantasm. In so far as there are only islands, there is no such thing as a cohesive or definitive thing as woman, just as there can be no cohesive category of man or animal (and to be sure, we could add an infinite number of determinations to this list).

But the eradication of the world poses a certain problem for Derrida: if there are only islands, how can there ever be a relation between individuals? Transposed into the sexual register, how is the sexual relation possible? The significance of the third thesis, and the conclusion that there is no world, only islands, is that all contact and a fortiori intimate contact is always already impossible. Which in a certain sense answers the once puzzling question of how Robinson Crusoe could live on his island for 26 years without one thought of a sexual partner, a sexual other. This contact is always already impossible, because, in a certain sense, the commonality of the world which would undergird and make possible such a relation is merely a phantasm. If Robinson Crusoe can never think of his sexual other, it is because philosophy has never properly thought the question of (sexual) relation.

Much of The Beast and the Sovereign II is concerned precisely with this question, with the possibility of relation as such. To articulate a possible solution, Derrida turns back to Defoe, to Robinson's deep and constant obsession with his own demise. In the logic of death, Derrida finds the possibility of relation even across islands. I would like to follow Derrida's analysis through his discussion of death in Robinson Crusoe to see what resources might be there for thinking the possibility of sexual relation in a world of radical difference. This move seems not to compromise the integrity of Derrida's thought because he seems to already have the erotic situation in mind in his discussion of death. He writes, "We shall be wondering, whether, in death and in mourning, things are not the same as they are in love, and whether loving does not mean.... to keep it [the object of love] living death in oneself."

\section{Death Comes to the Other}

The theme of death is an ever-present obsession for Robinson Crusoe. Derrida takes great pains to reproduce Crusoe's long meditations on his own demise. Derrida argues that Robinson Crusoe fears a certain kind of death more than any other, indeed more than death as such: death by devouring. The question arises naturally for Robinson Crusoe; insofar as he lives alone, vulnerable to whatever beast or man may come along and wish to dispose of him. But death by devouring is a specific kind of fear, precisely the fear of the "living death", being

${ }^{7}$ Ibid., 181.

(c) 2013 Ashley J. Bohrer http://www.kritike.org/journal/issue_12/bohrer june2013.pdf ISSN 1908-7330 
consumed, buried, eaten, taken over by the other as I live, in a certain sense being a party to, a witness to, having an experience of my own death. Derrida writes, "to mark the fact that 'dying a living death', being buried or swallowed up alive is indeed for Robinson to be delivered over, in his body, defenseless to the other." devouring takes on a much more trenchant philosophical significance for Derrida; insofar as one disposes of me, I encounter the Other. Playing here on the Levinasian definition of Otherness, Derrida takes Robinson Crusoe's fear of dying a living death to indicate the larger philosophical, cultural, and social anxiety of being delivered over, almost against one's own volition, to the other. It is in this moment, where I am delivered over to the other without resistance and without defense that the other can appear to me as Other.

This anxiety can be easily articulated via the concept of sovereignty. When "the other appears to me as the other as such, qua, he, she, or they who might survive me, survive my decease, and then proceed as they wish, sovereignly, and sovereignly have at their disposal in the future of my remains, if there are any." Robinson Crusoe's fear of death by devouring is thus much more a loss of sovereignty to the other. As we have already noted, in Western cultural memory, Crusoe stands as the lone man, stranded on his island, the paradigmatic figure able to make his own world, give himself the law, create, through the cunning of his mind and the sweat of his brow a world which is truly and irrevocably, his. If what makes Robinson Crusoe's story important, inseparable from the cultural tradition is in some sense his status as the metonym of modern sovereignty, then his fear of being devoured articulates the anxiety of a confrontation with the Other as other, a fear that my island of solitude might be breached by other forces, forces which can only be conceived as enemies. If Derrida insists that there is no world, only islands, the story of Robinson Crusoe articulates that we have always known this to be the case, that even the concept of the world in which the Other and I reside together is frightening and terrifying. Derrida writes, "that's what is meant, has always been meant, by 'other."'10

What Robinson's devouring represents then, a fortiori is the coconstitution of life and death. The paradoxical formulation of the 'living death' exposes the meaning of the Other, not only in relation to my death, but also to my life. Just as the other will dispose of my remains, if there are any, in the aftermath of my demise, the other may dispose of me in life, may dispose of me before I am yet dead. This is meaning of Derrida's provocative injunction that "one must therefore inscribe death in the concept of life." ${ }^{11}$ Derrida here is doing something much

\footnotetext{
${ }^{8}$ Ibid., 203.

${ }^{9}$ Ibid., 189.

${ }^{10} \mathrm{Ibid}$.

${ }^{11}$ Jacques Derrida, The Beast and the Sovereign, Volume I, trans. Geoffrey Bennington (Chicago: University of Chicago Press, 2011), 157.
}

(C) 2013 Ashley J. Bohrer http://www.kritike.org/journal/issue_12/bohrer june2013.pdf ISSN 1908-7330 
different than many of his contemporaries when they conceive of the primacy of the body in philosophy. All of the discourses of feminism, biopower, race theory, etc, all those philosophical positions which consider the relation of others to the body, they all consider the living body as their unit of analysis. Derrida, however, uses the motif of devouring in order to stage the problem of sovereignty over the dead body. The sovereignty of the Other over my remains is the moment in which I lose all control, all decision, all sovereignty. In this way, the dead body functions as what we might call an indicative limit case: Derrida uses the most extreme of situations to lay bare what is always-already the case in the broader and more common situations. Just as the other is sovereign over my remains, there is also a moment of sovereignty in all intimate relation in life.

If in life, as in death, I am always delivered over without defense to the Other, without reservation, resistance, or hesitation, then it is likewise true that the Other is always delivered over to me. In the context of the island, in which between me and any other, there remains 'the time and space of an infinite difference', then I must be obligated to deal with the other with respect to this difference. Derrida stages here the basis of responsibility and ethics as such as an imperative always to attend with meticulous and intimate care to the difference of the other. Here Derrida launches a reinterpretation of the closing line of Paul Celan's "Grosse, Glühende, Wölbung”: “Die Welt ist fort, ich muß dich tragen”, translated as "the world is lost, I must carry you." If the world is lost, Derrida argues, then the medium through which we might interact, our ground of commonality cannot furnish for us a mode of interaction. Instead, we can only interact from the position of our infinite differences.

Celan's poem provides the resources to reground Derrida's analysis in the sexual register. If we attend to the language of address Celan uses, we see that the poem can only be addressed to an intimate Other. In deploying the informal dich instead of Sie, Celan intimates that s/he who must be carried, born, supported, endured is precisely the one I would address intimately, closely, with affection. Between the space of infinitely different sexual constitutions, I must carry and support the sexual other, I must be militantly attentive to specificities of the other person(s) with whom I am engaged in a sexual scenario. The ethical injunction which comes with the erotic situation is the demand to be constantly vigilant, constantly present, constantly giving, ever more and more attentive to specificity of the irreducible singularity of the sexual being in front of me.

But what is most important to recognize in this situation is the dependence of the ethico-sexual injunction on the moment of sovereignty in all relation. When the other is delivered over to me without defense, when the lover gives him or herself over in vulnerability, it lays bare the constitutive moment of sovereignty. The requirement of care emerges from my power to dispose of the other with ruthless cruelty. This is what it means that in love, one keeps one's love object 
suspended in living death in oneself. It is because in the moment of love, as in death, that one is sovereign over the Other, and the other over oneself that any discourse of ethics is possible.

\section{The Politics of the Sexual Couple}

The account of sexuality I have sketched above presents us with a unique set of problems. Derrida goes quite a long way toward articulating a concept of sexuality that avoids the pitfalls of many of his predecessors. Responding to the problem of the binarity of sexual difference, Derrida lays the ground for an infinitely multiplicitous sexual difference. The issue that persists, however, is one which reactivates Derrida's differentiation between sexuality as such and sexual difference.

Where sexual difference has become multiple, we cannot escape the fact that erotic situation is always staged between two. Carried from the opening invocation of Volume I, "la... le," we see that the erotic play of language and concept relies inherently on one $l a$ and one $l e$, a pair, even a binary, which constitutes the erotic situation. We see again, a full year and hundreds of pages later, in the reinterpretation of Paul Celan, that the ethical invocation applied to the intimate other is always addressed in the singular: dich. Even as Derrida is able to think a dynamic, plastic, proliferating concept of sexual difference at the individual level, the moment that individuals is placed in an erotic relation, we see the reinstantiation of a rigid, uncritical reliance on the structure of relation as between two and only two.

Furthermore this pair, this couple, which is the subject of the sexual relation, always seems to be a heterosexual couple. Even after the destruction of the categories of male and female as true, eternal, or even as referring to something in the world, Derrida still uses the la of la bête or la femme and the le of l'homme or le souverain to stage the question of sexual relationship as such. Without an active disavowal or critique of this foundation, Derrida provides a few resources for thinking the erotic situation beyond the ethical injunction which structures it, to think any content of a radical sexual experience, relation, or concept. It is this question of the content of sex which Derrida leaves open and which calls out to be addressed.

That the sexual act is always monogamous, presupposes and imposes an exclusionary logic on desire. One of the material effects of infinitely singular individual sexualities must be that the object of desire will, at the very least for some, be polyamorous, nonheterosexual, autosexual. In addition to posing a philosophical concern, the return to the couple poses a political problem: are we able to think a sexual politics or a politics of sexuality within Derrida's text, or might we only be able think the constitution of an atomized individual's experience or the private sexual experience of a couple. Precisely what is necessary in order to think sex and 
politics together, to think the politicization of sexuality, the regulations, expectations, determinations of sexuality which happen at the level of social, political, and economic discourses, strategies, regulations, laws, transgressions, taboos, is to be able to think the erotic situation, not only between the couple, but as always, constituted beyond the two.

This concern about the status of politics within the discourse of sexuality arises internal to Derrida's own text and is both a problem and goal which he sets for himself. In articulating the aim of the seminar, Derrida grounds the import of the course precisely as responding to a set of political conditions and as furnishing the tools to forge a new political reality. He proclaims, "What I am seeking, elsewhere, but particularly in this seminar for would be, then, a prudent deconstruction of this logic [of sovereignty] and the classic, dominant concept of nation-state sovereignty (which is a reference to Schmitt) without ending up in a de-politicization, a neutralization of the political, but a re- polticization that does not fall into the ruts of a 'dishonest fiction'... that is, a new concept of the political." ${ }^{\prime 2}$

What does Derrida mean by this new concept of the political? He addresses it only briefly, but he does outline two conditions for this "slow and diferentiated deconstruction" of the logic of sovereignty: 1) that it will take shape according to the rhythm of the world, according to the way things actually unfold 2) that it cannot be a matter of simply frontally opposing sovereignty. ${ }^{13}$ Elaborating on the second condition, Derrida writes, "even in politics, the choice is not between sovereignty and non-sovereignty, but among several forms of pairings, partitions, divisions, conditions that come along to broach sovereignty that is always supposed to be indivisible and unconditional." ${ }^{\prime 4}$ We have seen that the categories of male and female cannot correspond to anything like the rhythm of the world, the actual and real practice and experience of sexuality. Indeed, they cannot have any referent even to the material body. And we cannot require Derrida to offer a vision of sexuality completely liberated from the frame of sovereignty that has been historically determined. What we can demand, or rather, what we must demand, however, is a politics of sexuality which does not pair, part, divide, and condition the sexual act in relation to heterosexual monogamy. In a certain sense, the call of this seminar entreats an opposition to certain logics of sovereignty and specifically, certain logics of sexual sovereignty.

It will not be enough to deconstruct the relationship between desire and sovereignty. By insisting on the absence of women on Robinson's island, Derrida calls attention to the myth of a sovereignty without desire, intimating that there is always a dimension of desire in sovereignty. Likewise, the discourse of the living death stages the sovereign moment in desire. But this is not enough. We might say

\footnotetext{
${ }^{12}$ Ibid., 112-113.

${ }^{13}$ Ibid., 114-115.

${ }^{14}$ Ibid., 114.
} 
that Derrida has fulfilled the first stage of the slow and differentiated deconstruction, reformulating sexual difference according to the actual rhythm, pace, and materiality of sex as it appears in the world, as irreducibly singular and unique. It is the second requirement for the foundation of a new politics, wherein we must resist certain configurations of sovereignty over others, and specifically the destructive, oppressive, repressive, and violent configurations of sovereignty, that remains to be fulfilled in this project. Given an entire history of social, political, economic, and philosophical texts which lay bare the violence of both monogamy and heteronormativity as violent arché imposed on desire (one could think here of Sade, Deleuze, Irigaray, Engels, Fourier, de Beauvoir, McClintock, Foucault, Ahmed, and the list goes on and on), given these insightful and productive texts, it seems as though in order to fulfill the project of a new politics, we must divorce both sovereignty and desire from the logic of male-female couple to which Derrida ultimately returns.

Department of Philosophy, DePaul University, United States

\section{References}

Derrida, Jacques, The Beast and the Sovereign, Volume I, trans. by Geoffrey Bennington (Chicago: University of Chicago Press, 2011). , The Beast and the Sovereign, Volume II, trans. by Geoffrey Bennington (Chicago: University of Chicago Press, 2011). , "Heidegger's Hand: Geschlecht II," in Psyche: Inventions of the Other, trans. by Peggy Kamuf and Elizabeth Rottenberg (Stanford: Stanford University Press, 2008). 